Kolmychkov, 2006 - Kolmychkov M. Bykorystannia elektronnykh atlasiv na urokakh heohrafii / M. Kolmychkov // Kraieznavstvo. Heohrafiia. Turyzm. - 2006. - №10-11. - S. 3-7.

Kushnarenko, 2014 - Kushnarenko Nataliia. Zastosuvannia inovatsiinykh tekhnolohii u navchanni fizychnoi heohrafii. / Nataliia Kushnarenko // Psykholoho-pedahohichni problemy silskoi shkoly. Vypusk 51. - 2014. - S. 52-58.

Markus, 2002 - Markus N. V. Osoblyvosti zastosuvannia informatsiinykh tekhnolohii yak zasobu humanizatsii navchannia shkoliariv / N. V. Markus // Onovlennia zmistu, form ta metodiv navchannia i vykhovannia v zakladakh osvity: 3b. nauk. pr. - Rivne. -2002 . - S. 171-173.

Nazarenko, 2008 - Nazarenko T. H. Zmist i struktura metodyky navchannia heohrafii v profilnii shkoli / T. H. Nazarenko // Heohrafiia ta osnovy ekonomiky v shkoli. - 2008. - № 7-8. - S. 18-20.

Novykov, 2003 - Novykov S. P. Prymenenye novыkh ynformatsyonnыkh tekhnolohyi v obrazovatelnom protsesse / S. P. Novykov // Pedahohyka. - 2003. - № 9. - S. 32-38.

Pekhota, 2004 - Pekhota O. M. Osvitni tekhnolohii / za red. O. M. Piekhoty. - K., 2004. - S. 44-46.

Pyrohov, 2011 - Pyrohov I. Multymediini zasoby u navchanni heohrafii / I. Pyrohov // Kraieznavstvo. Heohrafiia. Turyzm. - 2011. - № 38. - S. 7-8.

Pometun, 2004 - Pometun O. I. Suchasnyi urok. Interaktyvni tekhnolohii navchannia: naukovo-metodychnyi posibnyk / O. I. Pometun, L. V. Pyrozhenko. - K.: Vydavnytstvo A.S.K., 2004. - 192 s.

Інна Кононенко, кандидат педагогічних наук, старший викладач кафедри іноземної філології,

перекладу та методики навчання

ДВНЗ «Переяслав-Хмельницького державного педагогічного університету

імені Григорія Сковороди».

\section{Inna Kononenko,}

PhD in Pedagogy, Senior Lecturer

of the Department of Foreign Philology,

Translation and Teaching methods

State Higher Education «PereiaslavKhmelnytskyi Hryhorii Skovoroda State

Pedagogical University».

E-mail: innakononenko83@ukr.net

ORCID 0000-0001-9553-5339

\title{
МУЛЬТИКУЛЬТУРАЛІЗМ ЯК ПЕРЕДУМОВА ПІДГОТОВКИ МАЙБУТНІХ УЧИТЕЛІВ ФІЛОЛОГІЧНИХ СПЕЦІАЛЬНОСТЕЙ У КОНТЕКСТІ ІНТЕГРАЦІЙНИХ ТА ГЛОБАЛІЗАЦІЙНИХ ПРОЦЕСІВ СВІТУ
}

У статті розглянуто концепцію мультикультуралізму як передумову підготовки майбутніх учителів філологічних спеціальностей у контексті інтеграційних та глобалізаційних процесів у світі. Визначено концепції підготовки кваліфікованих майбутніх спечіалістів філологічних спеціальностей у площині мультикультуралізму. Виокремлено основні принципи основні напрямки професійного становлення майбутніх учителів філологічних спеціальностей у практиці вищої школи, щзо включають ознайомлення студентів з проблемами становлення та розвитку мультикультурних суспільств, різними аспектами спілкування $i$ стосунків між людьми в них. Охарактеризовано засоби підготовки студентів до міжкультурної комунікації в ході вивчення іноземних мов, формування у майбутніх учителів філологічних спеціальностей інтересу до професійної діяльності, підготовка студентів до використання педагогічних технологій в освітньому процесі для вирішення конкретних навчально-виховних завдань. Розглянуто сучасне реформування системи освіти Украӥни як один з компонентів євроінтеграційного процесу, де набуває актуальності питання використання міжпредметних зв'язків між викладанням іноземних мов $i$ міжкультурною комунікацією. Проаналізовано зв'язок між викладанням іноземних мов і міжкультурною комунікацією з позицій мультикультуралізму. Комунікативний аспект розглядається як основа взаємодії майбутніх фахівці філологічних спечіальностей, який передбачає реалізацію мети спілкування між різними соціокультурними групами. Застосування знань про іншомовний соціум забезпечують широкий спектр міжкультурного спілкування, формують готовність студентів до якісного міжкультурного ділового спілкування, до міжнародного професійного співробітництва. Навчання кваліфікованих фахівців філологічних спеціальностей у сфері мультикультуралізму спрямоване на засвоєння іноземної мови на внутрішньому рівні; застосовувати на практиці навички та знання іноземної мови; покрамення інтелектуального, загальнокультурного рівня майбутніх фахівців; для занять особистим розвитком; застосування етичних норм спілкування та їх застосування на практиці. 
Ключові слова: мультикультуралізм, міжкультурної комунікації, майбутні учителі філологічних спеціальностей, професійне становлення, міжнародне професійне співробітництво, педагогічні технології.

The article considers the concept of multiculturalism as a prerequisite for the training of future teachers of philological specialties in the context of integration and globalization processes in the world. The concept of preparation of qualified future specialists of philological specialties in the field of multiculturalism is determined. The basic principles of the professional formation of future teachers of philological specialties in the practice of higher education are set out, including familiarizing students with the problems of formation and development of multicultural societies, various aspects of communication and relations between people in them. The means of preparation of students for intercultural communication in the course of studying foreign languages, formation of interest in professional activity of future teachers of philological specialties, preparation of students for the use of pedagogical technologies in the educational process for solving specific educational and educational tasks is described. The current reform of the educational system of Ukraine is considered as one of the components of the European integration process, where the issue of the use of interdisciplinary connections between teaching foreign languages and intercultural communication becomes relevant. When teaching a foreign language, the foundations of another culture are recognized, as each foreign word reflects a different culture; each token has a certain image, due to the linguistic historical tradition of the people. There is a close link between the teaching of foreign languages and intercultural communication. From the standpoint of multiculturalism, the communicative aspect is considered as a basis for the interaction of future specialists in philological specialties mastering key information about the process of communication, which involves active social interaction of individuals, follow the rules and norms aimed at achieving the goal of communication between different socio-cultural groups. The training of qualified specialists in philological specialties in the field of multiculturalism is aimed at mastering a foreign language at the domestic level; apply skills and knowledge of a foreign language in practical activities; improvement of the intellectual, general cultural level of future specialists; for occupation by personal development; application of ethical norms of communication and their application in practice.

Keywords: multiculturalism, intercultural communication, future teachers of philological specialties, professional formation, international professional co-operation, pedagogical technologies.

Постановка проблеми. 3 активним розвитком глобалізації у єдиному світовому просторі представники різних етнокультур визнають значні зміни й в його історико-соціологічній концепції. Однією 3 концепцій глобального суспільства $\epsilon$ розробка теорії мультикультуралізму, що стверджує невідворотність інтеграційних процесів різних культур та їх асиміляції.

Аналіз останніх досліджень $і$ публікацій. Концепт мультикультуралізму у наукових працях досліджується останні кілька десятиліть. На теренах української наукової площини питання впливу міжкультурної комунікації та міжкультурної комунікативної компетенції у вищій школі при вивченні та викладанні іноземних мов, підготовці майбутніх вчителів філологічних спеціальностей займалися Литовченко Н., Манакін В., Каніболоцька О., Тупченко В. та інші. Реформування системи освіти України, як один 3 компонентів євроінтеграційного процесу, де набуває актуальності питання використання міжпредметних зв'язків між викладанням іноземних мов i міжкультурною комунікацією, зв'язок між викладанням іноземних мов і міжкультурною комунікацією науковці розглядають 3 позицій мультикультуралізму та комунікативний аспект, як основа взаємодії майбутніх фахівці філологічних спеціальностей, що передбачає реалізацію мети спілкування між різними соціокультурними групами.

Mema cmammi - здійснити теоретичний аналіз поняття мультикультуралізм та визначити вплив суспільно-політичних мультикультурних процесів на особливості концепції підготовки майбутніх вчителів філологічних спеціальностей.

Виклад основного матеріалу. Суспільно-політичні процеси кінця ХX початку XXI століття та історичні обставини розвитку призвели до поширення у суспільстві явища як мультикультуралізм. Так як соціо-культурні норми суспільства набувають розвитку виключно у системній взаємодії мовних, 
культурних та соціально-історичних аспектів різних етнічних груп, проблему мультикультуралізму слід розглядати як теоретичну ідеологему. Спосіб реалізації етнонаціональної політики держави, визначають наукові підходи до мультикультуралізму як соціального феномена та його практичні (політичні) складові, аналізуються сучасні типології прикладних моделей [Горбунова, 2009: c. 38].

Мультикультуралізм передбачаєм врахування відмінностей етнокультур практикою неконфліктного співіснування в одному життєвому просторі значної кількості культурних груп. Таким чином, мультикультуралізму включає в себе різні теоретико-методологічні підходи, різноманіття поглядів щодо розв'язання соціальних, політико-правових проблем, формування мультикультурального суспільства відповідно до сучасних соціально історичних особливостей.

Розглядаючи культуру як засіб самореалізації, розвитку та самовдосконалення особистісних та комунікативних навичок індивіда, можна диференційовано підійти до розуміння історичних форм культури освітніх процесів. Ключова роль учителів у модернізації європейської освіти підкреслюється в рамках усіх фундаментальних документів, що визначають сутність сучасної освітньої політики СС. Це і резолюція Сврокомісії «Про розвиток неперервної освіти», і «План дій щодо розвитку професійних умінь та професійної мобільності», і Болонська та Копенгагенська декларації, і План розвитку дистанційної освіти, і багато інших. Визначення стратегічних напрямів розвитку педагогічної освіти стало пріоритетом діяльності спеціальної групи європейських експертів - «Удосконалення освіти вчителів та інструкторів» (Working group A «Improving the Education of Teachers and Trainers»), яка перш за все сформулювала вимоги до формування широкого спектру нових компетентностей учителя, зумовлених змінами у політичному, соціальному, культурному, технологічному та економічному житті сучасного європейського суспільства Розробка єдиних стандартів якості педагогічної освіти, професійного розвитку та педагогічної діяльності $€$ запорукою того, що всі національні освітні системи рухаються у напрямі все більшої відповідності діяльності вчителя актуальним потребам суспільного життя національних держав та Європейського регіону в цілому [Сбруєва, 2007: с. 2].

Сучасне реформування системи освіти України $є$ одним 3 компонентів євроінтеграційного процесу. Тому набуває актуальності питання використання міжпредметних зв'язків між викладанням іноземних мов i міжкультурною комунікацією. При викладанні курсу іноземної мови пізнаються основи іншої культури, оскільки кожне іноземне слово відображає іншу культуру, за кожною лексемою стоїть певний образ, зумовлений мовною історичною традицією народу.

Сучасний стан професійного становлення майбутніх учителів філологічних спеціальностей має низку особливостей. Перш за все актуальним є вивчення студентами закономірностей функціонування сучасного мультикультурного суспільства та відповідної моделі поведінки і спілкування між людьми. Професійна діяльність майбутнього фахівця передбачає комплексне і варіативне використання теоретичних знань та практичних умінь. Кожне професійне завдання, по суті, $\epsilon$ міждисциплінарним, інтегральним і вимагає системного аналізу, побудови цілісної моделі його вирішення. Сказане пояснює, чому підготовка фахівців, необхідних державі і націлених на успішну трудову діяльність, неможлива без дотримання інтегративного підходу в професійній освіті. 
Професійне становлення майбутніх учителів філологічних спеціальностей визначається різними аспектами. Набуває актуальності вивчення майбутніми педагогами функціонування сучасного мультикультурного суспільства та формування рефлекторної моделі функціонування та комунікації в ньому.

Майбутні вчителі філологічних спеціальностей повинні сприймати явище мультикультуралізму як проблему стратегії та ідеології, що стверджує значимість існування різноманітних культурних форм. Передумовою такої підготовки студентів $\epsilon$ інтеграційні та глобалізаційні процеси у світі, що об'єктивно ведуть до змішування різних етносів й етнічних культур. Існування на межі різних культур, взаємодія 3 ними вимагає від вчителів-філологів діалогічності, розуміння, поваги до культурної ідентичності інших людей та формування відповідних рис у підростаючого покоління [Козловецьь, 2011: с. 152-154].

Соціальне оточення студентів філологічних спеціальностей дає змогу оцінити їхній соціальний статус, визначити основні ролі. Заклади вищої освіти залучають майбутнього вчителя філологічних спеціальностей до виконання професійних дій, що забезпечує активізацію його самостійності. Протягом періоду навчання студенти приєднуються до системи соціально-трудових відносин та сфери професійного спілкування. Таким чином, контактна група активізує, сприяє застосуванню та вдосконаленню професійних навичок та інтересів особистості.

За сприятливого середовища в закладі освіти, яке сприяє розвитку моральних якостей, соціально значущих цінностей, розкриттю творчого потенціалу особистості, оновленням змісту наявних і появою нових гуманітарних дисциплін, упровадженням новітніх педагогічних технологій, переорієнтацією всього освітнього процесу на оволодіння прийомами професійно-педагогічної діяльності, спрямованої на формування наукового світогляду й гуманістичних та мультикультурних ідеалів.

Аналіз змісту професійної підготовки дає можливість визначити низку професійно важливих характеристик майбутнього вчителя філологічних спеціальностей:

- має знання з історії, сучасного стану та перспектив розвитку філологічної науки;

- володіє українською мовою;

- володіє іноземною мовою;

- обізнаний із сучасними проблемами мовознавства;

- знає український фольклор;

- має знання з української і зарубіжної літератури;

- володіє основними методами лінгвістичного й літературознавчого аналізу;

- володіє теорією і методикою навчання філологічних дисциплін;

- знає основи національної культури, традицій та звичаїв свого народу;

- обізнаний 3 основами національної культури інших країн, традицій i звичаїв народів світу (відповідно до специфіки іноземної мови);

- уміє користуватися різноманітними джерелами для здійснення професійної діяльності та навчання;

- здатен здійснювати рефлексивний аналіз;

- уміє здійснювати аналіз психолого-педагогічного стану учня й колективу;

- уміє планувати та проводити заняття в різних формах тощо.

Головними цілями підготовки майбутніх вчителів філологічних спеціальностей до міжкультурної комунікації є такі 
- систематичне викладення основних проблем міжкультурної комунікації, оволодіння основними поняттями і термінологією;

- розвиток культурної сприйнятливості, здатність до правильної інтерпретації конкретних проявів комунікативної поведінки в різних культурах;

- формування практичних навичок і вмінь в спілкуванні з представниками інших культур [Тупченко, 2013: с. 199-204].

Між викладанням іноземних мов і міжкультурною комунікацією існує тісний зв'язок. 3 позицій мультикультуралізму комунікативний аспект розглядається як основа взаємодії майбутніх фахівці філологічних спеціальностей засвоюють ключові відомості про процес спілкування, котрий передбачає активну соціальну кооперацію взаємодію індивідів, слідують правилам і нормам, що мають за мету реалізацію мети спілкування між різними соціокультурними групами.

Формування комунікативних навичок та засобів їх реалізації у майбутніх учителів філологічних спеціальностей вимагає наявності наступних моральних якостей: терпимість, доброзичливість, повага до людей, тактовність і чемність. Культура спілкування має велике значення для встановлення оптимальних соціально-психологічних зв'язків у суспільстві, трудовому колективі, освітньому процесі та побутовій сфері.

У результаті вивчення іноземної (живої) майбутні вчителі мають вільно володіти поняттями, методами та прийомами; володіти необхідним дидактичним матеріалом з відповідних дисциплін, враховуючи міжпредметні зв'язки; толерантно мобілізувати учнів на виконання завдань; використовувати здобуту інформацію, збагачувати власну культуру в різноманітних аспектах трудової діяльності, бути соціально активним членом суспільства, бути відкритим в умовах чесної рівності можливостей для усіх громадян, у тому числі й незалежно від статі, раси, етнічної належності чи соціального походження, розуміти потреби суспільства як форми соціальної кооперації.

Підготовка майбутніх вчителів філологічних спеціальностей включає вивчення сукупності невербальних засобів комунікації, історичних та національних традицій народів країн, мови яких вивчаються. Значно полегшує взаємовідносини із представниками іншомовних груп розуміння мови жестів, що дає змогу частково компенсувати незнання мови завдяки вмінню правильно іiі трактувати,

Завдання навчання іноземних мов як засобу комунікації між представниками різних народів і культур полягає в тому, що мови повинні вивчатися в нерозривній єдності зі світом і культурою народів, що говорять на цих мовах. До основних компонентів подібної іноземної культури, які повинні засвоїти студенти філологи належать наступні елементи, що мають відповідне національно-специфічне забарвлення:

- традиції, а також обряди, які можна сприймати як традиції;

- традиційно-побутова культура;

- повсякденна поведінка;

- національна картина світу, яка відображає специфіку сприйняття навколишнього світу;

- художня культура, яку можна також віднести до елементів етнографії та етнології [Верещзагін, 1980: с. 320].

Комунікацію, як міжособистісний процес обміну інформацією за допомогою різних вербальних і невербальних комунікативних засобів, майбутні вчителі філологічних спеціальностей розглядають як соціально зумовлений процес 
обміну думками і почуттями між людьми в різних сферах їхньої пізнавальнотрудової й творчої діяльності, що реалізується головним чином за допомогою вербальних засобів комунікації.

Вагомими цілями підготовки майбутніх вчителів філологічних спеціальностей до міжкультурної комунікації є:

- систематичне викладення основних проблем міжкультурної комунікації, оволодіння основними поняттями і термінологією;

- розвиток культурної сприйнятливості, здатність до правильної інтерпретації конкретних проявів комунікативної поведінки в різних культурах;

- формування практичних навичок і вмінь у спілкуванні 3 представниками інших культур [Тупченко, 2013: с. 200-201].

У процесі вивчення міжкультурної комунікації між представниками різних націй і культур студенти засвоюють елементи, яких слід уникати, щоб не зіпсувати спілкування ще до його початку: нетактовне для певної культури звертання до людини; різнобій тлумачень та мовних порівнянь; помилкове вживання міжмовних омонімів, які спричинюють непорозуміння, комічні ситуації, а часом навіть конфлікти [Манакін, 2012: с. 288].

Майбутні вчителі філологічних спеціальностей повинні бути готовими до міжкультурного спілкування із представниками інших країн, уміти знаходити нестандартні рішення у незнайомих міжкультурних ситуаціях. У навчальній діяльності студентів філологічних спеціальностей найважливішу роль відіграє усна комунікація.

Інтерактивні методи (ділові та рольові ігри, дискусї тощо) дають студентам змогу опанувати мистецтво ведення переговорів з іноземцями, розвивати вміння і навички працювати командно, з урахуванням культурних особливостей ділового партнера [Литовченко, 2015: с. 76].

Володіння іншомовним кодом, за допомогою якого майбутні учителі філологічних спеціальностей успішно здійснюватимуть міжкультурно-професійну взаємодію, передбачає формування не тільки практичних навичок усного мовлення, а й професійно важливих концептів іншомовної культури, що визначають специфіку суспільної й ділової поведінки, детермінованої впливом історичних традицій і звичаїв, способу життя тощо. Лінгвосоціопсихологічні та культурологічні знання про іншомовний соціум створюють широкий контекст міжкультурного спілкування, формують перцептивну готовність студентів до ефективного міжкультурного ділового спілкування, до міжнародного професійного співробітництва [Каніболоцька, 2011: с. 100].

Підготовка кваліфікованих спеціалістів філологічних спеціальностей у площині мультикультуралізму спрямована на оволодіння іноземною мовою на побутовому рівні; застосовувати навички та знання іноземної мови у практичній діяльності; підвищення інтелектуального, загальнокультурного рівня майбутніх спеціалістів; для занять особистісним розвитком; застосування етичних норм комунікації та їх застосування на практиці.

Висновки. Основні напрямки професійного становлення майбутніх учителів філологічних спеціальностей у практиці вищої школи включають ознайомлення студентів з проблемами становлення та розвитку мультикультурних суспільств, різними аспектами спілкування і стосунків між людьми в них, підготовку студентів до міжкультурної комунікації (спілкування) в ході вивчення іноземних мов, формування у майбутніх учителів філологічних спеціальностей 
інтересу до професійної діяльності, підготовка студентів до використання педагогічних технологій в освітньому процесі для вирішення конкретних навчальновиховних завдань. Це дає можливість розглядати мультикультуралізм як передумову підготовки майбутніх учителів філологічних спеціальностей у контексті інтеграційних та глобалізаційних процесів у світі.

Перспективи подальших наукових досліджень. Перспектива подальших наукових досліджень полягає у активному розвитку формування концепції підготовки майбутніх вчителів філологічних спеціальностей 3 позиції впливу міжкультурної комунікації та політики міжкультуралізму.

\section{ЛІТЕРАТУРА}

Верещагин, 1980 - Верещагин Е.М., Костомаров В.Г. Лингвострановедческая теория слова. М.: Русский язык, 1980. С. 199-204.

Горбунова, 2009 -- Горбунова Л. Мультикультуралізм як теоретична та практична проблема: орієнтири для освіти: круглий стіл в редакції журналу «Філософія освіти» // Філософія освіти: наук. часопис. 2009. № 1-2 (8). К.: Вид-во НПУ імені М.П. Драгоманова, 2009. С. 35-44.

Каніболоцька, 2011 -- Каніболоцька О.А. Вивчення «невдач» міжкультурної комунікації в процесі навчання іноземної мови у вищій школі // Ученые записки Таврического национального университета имени В.И. Вернадского. Серия: «Филология. Социальные коммуникации». 2011. Т. 24 (63). № 2. Ч. 1. C. 98-101.

Козловець, 2011 -- Козловець М.А. Мультикультуралізм і проблема єдності українського суспільства / М.А. Козловець // 20 років незалежності України: здобутки, втрати і стратегії майбутнього: XI наук.-практ. конф. / Нац. акад. управління, Центр перспективних соц. досліджень. - К. : ЛазуритПоліграф, 2011. - С. 152-154.

Литовченко, 2015 -- Литовченко Н.А. Розвиток міжкультурної комунікативної компетенції студентів у процесі вивчення ділової іноземної мови // Вісник Дніпропетровського університету. Серія «Мовознавство». 2015. № 11. Вип. 21 (3). С. 75-78.

Манакін, 2012 -- Манакін В.М. Мова і міжкультурна комунікація: [навч. посібн.]. К.: «Академія», 2012.288 с.

Сбруєва, 2007 -- Сбруєва А.А. Тенденції розвитку європейського простору педагогічної освіти в умовах побудови суспільства знань. 2007. С. 2. http://eprints.zu.edu.ua/2076/1/08saapsz.pdf

Тупченко, 2013 -- Тупченко В.В. Викладання іноземної мови як засобу міжкультурної комунікації у вищій школі / В.В. Тупченко // Духовність особистості: методологія, теорія і практика. 2013. № 5 (58). C. 199-204.

\section{REFERENCES}

Vereshchahyn, 1980 - Vereshchahyn E.M., Kostomarov V.H. Lynhvostranovedcheskaya teoryya slova. M.: Russkyy yazyk, 1980. 320 S. 199-204.

Horbunova, 2009-- Horbunova L. Mul'tykul'turalizm yak teoretychna ta praktychna problema: oriyentyry dlya osvity: kruhlyy stil v redaktsiyi zhurnalu «Filosofiya osvity» // Filosofiya osvity: nauk. chasopys. 2009. № 1-2 (8). K.: Vyd-vo NPU imeni M.P. Drahomanova, 2009. S. 35-44.

Kanibolotska, 2011 - Kanibolots'ka O.A. Vyvchennya «nevdach» mizhkul'turnoyi komunikatsiyi v protsesi navchannya inozemnoyi movy u vyshchiy shkoli // Uchenye zapysky Tavrycheskoho natsyonal'noho unyversyteta ymeny V.Y. Vernadskoho. Seryya: «Fylolohyya. Sotsyal'nye kommunykatsyy». 2011. T. 24 (63). № 2. CH. 1. S. 98-101.

Kozlovets, 2011 - Kozlovets' M.A. Mul'tykul'turalizm i problema yednosti ukrayins'koho suspil'stva / M.A. Kozlovets' // 20 rokiv nezalezhnosti Ukrayiny: zdobutky, vtraty i stratehiyi maybutn'oho: KHI nauk.prakt. konf. / Nats. akad. upravlinnya, Tsentr perspektyvnykh sots. doslidzhen'. - K. : Lazuryt-Polihraf, 2011. - S. 152-154.

Lytovchenko, 2015 - Lytovchenko N.A. Rozvytok mizhkul'turnoyi komunikatyvnoyi kompetentsiyi studentiv u protsesi vyvchennya dilovoyi inozemnoyi movy // Visnyk Dnipropetrovs'koho universytetu. Seriya «Movoznavstvo». 2015. № 11. Vyp. 21 (3). S. 75-78.

Manakin, 2012 - Manakin V.M. Mova i mizhkul'turna komunikatsiya. K.: «Akademiya», 2012. 288 p.

Sbruyeva, 2007 - Sbruyeva A.A. Tendentsiyi rozvytku yevropeys'koho prostoru pedahohichnoyi osvity v umovakh pobudovy suspil'stva znan'. 2007. S. 2. http://eprints.zu.edu.ua/2076/1/08saapsz.pdf

Tupchenko, 2013 - Tupchenko V.V. Vykladannya inozemnoyi movy yak zasobu mizhkul'turnoyi komunikatsiyi u vyshchiy shkoli / V.V. Tupchenko // Dukhovnist' osobystosti: metodolohiya, teoriya i praktyka. 2013. № 5 (58). S. 199-204. 